論文

\title{
立体を好ましく見せるための照明条件に関する研究 (1)
}

\author{
専門会員 故阪口 忠雄* 専門会員 江島 義道* 専門会員 永井 久*
}

\author{
A Study on the Lighting Conditions Required for \\ Preferable Appearance of Solid Objects (1) \\ The late Dr. Tadao Sakaguchi (Fellow Member) \\ Yoshimichi Ejima (Fellow Member) \\ Hisashi Nagai (Fellow Member) \\ (Faculty of Engineering, Kyoto University)
}

\begin{abstract}
In order to establish a comprehensive method for adequate illumination of solid objects, the following questions must be clarified.

How may the three-dimensional distribution of light exert influence on appearance of solid objects?

To clarify this question, many studies such as Moon and Spencer's, Hewitt's, Cuttle's and Fischer's were carried out.

But many problems to be solved have been left as yet.

The purpose of this study is to examine the following problems.

(1) What are the lighting conditions required for preferable appearance of solid objects when a small source is used as a directional lighting?

(2) How may size of directional lighting exert influence on appearance of solid objects?

Several experiments are carried out to examine the first.

The following are Clarified.

(1) Preferable direction of the flow of light

(2) Preferable ranges of the vector: scalar ratio
\end{abstract}

1. 序論

従来の室内照明設計の基礎は明視論であり，照度レベ ルがもっとも重要な設計要因とされていた. しかし近年 人間性を尊重した快適な環境づくりが，視環境設計の目 標とされるようになり，人間の心理的要因も重要視され るようになった，そしてその一つの要因として，「室内 の在室者などの視対象物がはっきりと好ましく見える」 ことが大切な問題として取り上げられた. ところで視対象立体の見方方は, その物体の置かれて

* 京都大学工学部

Vol. 59 No. 1
いる水平面照度よりも，その物体を照明する際の光の当 て方のほうが，より一層大きな影響力を持っていると考 えられる. 光の方向, 強さ, 拡散性の光々指向性の光の バランス, 指向性の光の広がり, 視線と光の方向の関係 などが見方方を大きく左右する.

したがって，立体の形を照明によって適切に表わす方 法を確立するためには，まず光の当て方を規定する種々 の物理的要因が，立体の好ましい見え方にどのような影 響を与えるかを明らかにする必要がある.

このような要請にこたえるために，すでに一連のモデ リングに関する研究が行なわれている. その代表的例之 しては Moon \& Spencer ${ }^{1)}$, Hewitt ${ }^{2)}$, Cuttle ${ }^{3)}$, Fischer ${ }^{4}$ 
らの成果があげられる. しかしモデリングインデックス の決定，あるいはインデックスの好ましい範围の定量的 設定については，まだ結論に達していないというべき で5)，種々の問題が今後の課題として残されている.そ こで筆者らは，この課題の中から次の二つの問題を取り 上げ，それについて実験的検討を行なった。

（1）指向性の光として，点光源を用いた場合の好まし いモデリング効果を与える照明の所要条件は何か。

（2）指向性用光源の大きさの変化は，モデリング効果 にどのような影響を与えるか.

本稿では二つの問題のうち, まず(1)についての検討結 果を報告する.

\section{2. 用語と記号}

まず本稿で使用する用語, 記号について説明する.

\section{1 照度ベクトルとその方向}

図 1 は锶察者, 視対象物, 指向性用光源の位置関係 を示したものである. 光源から視対象物への方向は照度 ベクトルの方向を示し，これは視線とのなす鉛直方位角

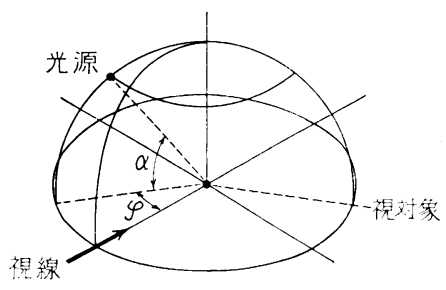

図 1 照度ペクトルの方向

と水平方位角で表わすことができる。ここでは，これら をそれぞれ，高度 $\left(\alpha^{\circ}\right)$, 方位 $\left(\varphi^{\circ}\right)$ で表わすことにした。

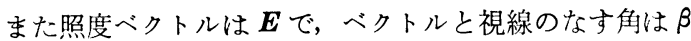
で表わすことにした。

\section{2 ス ラ照度}

スカラ照度は, 被照点㯰いた小球表面上の平均照度 と定義されるものである.ここではこれを $E_{s}$ で表わす.

\section{3 指向性の光の広がり}

指向性の光の広がりを，どのように表示すべきかにつ いては種々の論議があると思われるが，ここでは視対象 の置かれている点から光源をみたときの，光源のはる最 大角で表わすことにし，これをいしとする.

\section{4 インデックス}

モデリング効果を表わすインデックスとして，何を採 用すべきかについては後で検討することにし，とりあ古 ずCuttle らが提案したべクトル：スカラ比（以下こ れを $\boldsymbol{E}: E_{s}$ と略述する）を用いて，実験結果の概要を 説明する.

\section{3. スカラ照度の測定}

スカラ照度は, 小球表面の平均照度と定義されるもの であり，従来の照度計ではこれを測定することはできな い、そこで筆者らは新たにスカラ照度計を作製した。

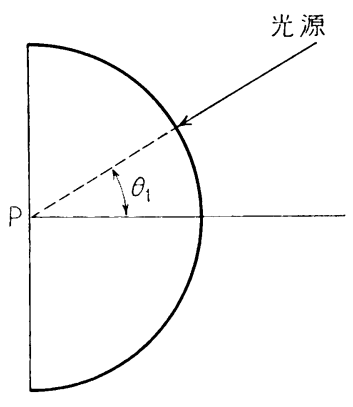

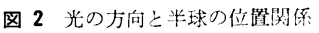

図 2 に示すように，点 $\mathrm{P}$ を中心とする小球に点光源 からの光が入射したとすると, 半球面上の平均照度 $E_{m h}$ は次式で与兄られる。

$$
E_{m h}=\frac{1}{4}\left(1+\cos \theta_{1}\right) E_{D 1}
$$

ここで， $E_{D_{1}}=$ 照度計を光の入射方向に垂直に置いた ときの照度

$\theta_{1}=$ 光の入射方向と半球の中心軸のなす角

第 2 , 第 $3, \cdots \cdots+$ などの多数の点光源が存在するとき は $E_{m h}$ は次式で示される.

$$
\begin{aligned}
E_{m h}= & \frac{1}{4}\left(1+\cos \theta_{1}\right) E_{D 1} \\
& +\frac{1}{4}\left(1+\cos \theta_{2}\right) E_{D 2}+\cdots \cdots \\
= & \frac{1}{4}\left(E_{D 1}+E_{D 2}+\cdots \cdots\right) \\
& +\frac{1}{4}\left(E_{D 1} \cos \theta_{1}+E_{D 2} \cos \theta_{2}+\cdots \cdots\right) \cdots(2)
\end{aligned}
$$

ここで，第 1 項は複数点光源による球面上の平均照度 (すなわちスカラ照度) であり, 第 2 項は照度ベクトル の半球の軸方向成分の $1 / 4$ である. この関係式は線光 源, 面光源の場合にも当てはまる ${ }^{6)}$. したがって半球の 軸を照度ベクトルの方向に直角になるよらにすれば, 半 球の平均照度はスカラ照度と等しくなり, 半球の照度計 によってスカラ照度を測定できる。

本研究では, 半球の平均照度が測定できる照度計を作 製し、これによってスカラ照度を測定した。照度計はピ ンポン球を半分に切って，その内部にセレン光電池を設 置して作った。ところがこのままでは角度特性が良好で ない，点光源が一つの場合は角度特性は (1) 式侸がう べきであるが，受光面が半球の軸と垂直になっているた 


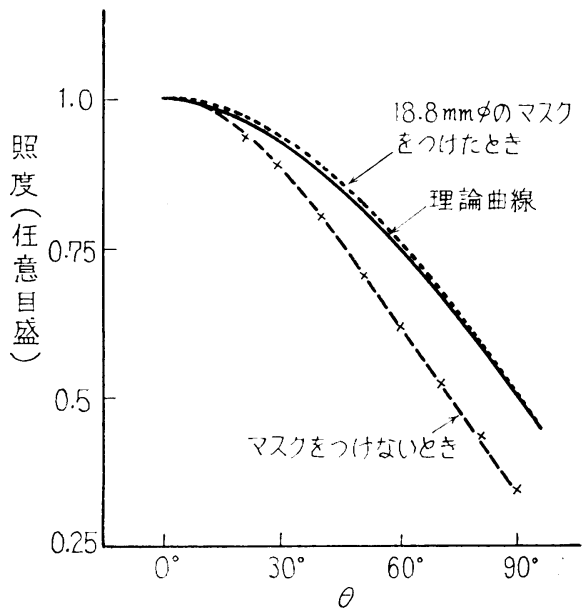

図 3 照度計の角度特性

め, 軸方向から入射する光が相対的に強く感じられ，角 度特性が理論曲線からずれてくる（図 3 参照).

そこで何らかの方法で，この角度特性のずれを補正す る必要がある.

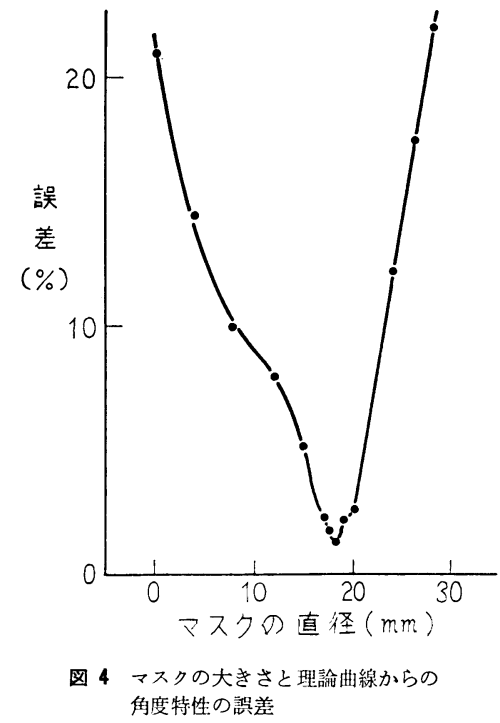

ここでは，半球の天頂に黒いマスクをつけることによ ってこれを達成した、マスクをつけたときの角度特性の 理論曲線からのずれは，マスクの大きさによって変化す る. 図 4 は角度特性のずれと, マスクの大きさの関係を 示したものである. 図から，マスクの大きさが $18.8 \mathrm{~mm}$ $\phi$ のとき,ずれがもっとも小さくなることがわかる. こ の結果から，角度補正用のマスクとしては， $18.8 \mathrm{~mm} \phi$ のものを採用することにした。このときの䛊差は $1.4 \%$ であり，角度特性は図 3 に示すように理論曲線とかなり よく一致する.

本研究のスカラ照度は, この照度計を用いて測定し た.

\section{4. 指向性の光として点光源を用いた場合のモ デリング効果}

\section{1 予備実験の結果}

実験上の問題点を探し、より効果的に実験を行ならた めに, 一辺が $180 \mathrm{~cm}$ の立方体の央験室を作り予供的検 討を行なった，その結果をまとめると次のようになる.

（1）モデリング効果の好ましさの評定実験では，被験 者を教示や練習によって十分訓練する必要がある. 特に 観測の初期においては，好ましい $\boldsymbol{E}: E_{s}$ が高くなる傾 向がみられるので十分の配慮が必要である.

（2）近視の人が好ましいとする $\boldsymbol{E}: E_{\boldsymbol{s}}$ は，正常の人 のそれに比べ高くなる傾向がある.

（3）照度ベクトルの方向は $\alpha=-45 \sim 90^{\circ}, \varphi=0$ ～ $120^{\circ}$ の範囲で変化すれば十分である. $\alpha<-45^{\circ}$ なな $\varphi>120^{\circ}$ のベクトルの方向に対しては，好ましいモデリ ング効果は得られない。

(4) 照度ベクトルの方向は，できるだけ小きざみに変 えるほらがよい、モデリング効果の現われ方は方向によ って急に変化するので, 現象を精確に把握するためには ベクトルの方向の変化を，できるだけ小きざみにした汪 らがよい.

（5）好ましいと評定される $\boldsymbol{E}: E_{\boldsymbol{8}}$ は，照度レベルに よって変わらない. 照度レベルによって好ましいと評定 される $\boldsymbol{E}: E_{s}$ に差があるかを調べるために，照度レべ ルを種々に変化させて $\left(E_{s}=10 \sim 3001 \mathrm{x}\right)$ 実験を行なっ た、結果の差を $\mathrm{F}$ 検定によって検討したところ，5\%有 意水準で有意な差は見られず，照度レベルが極端に低い 場合を除けば，好ましいと評定される $\boldsymbol{E}: E_{s}$ は，照度 レベルによって変化しないことが明らかになった。

（6）指向性の光源の位置は，視対象からできるだけ遠 く, ベクトルの方向によって変わらないほらがよい.人 の顔のような視対像立体はかなり不規則であり，顔の表 面は必ずしも同一球面上にはない，したがって光源の位 置が近いか，または方向によって距離が異なれば $\boldsymbol{E}: E_{s}$ をどの点でとらえるかが問題となる。

本実験は, 以上のような予備的実験結果から得られた 知見を基盤にして計画, 実施した.

\section{2 実験装置と視対象}

拡散性の光が任意の強さに, 指向性の光が任意の位置 と，任意の強さに設定できる一辺が $260 \mathrm{~cm}$ の立方体の 実験室を作製した。図 5 はその概観を示したものであ る. 拡散性の光は, 立方体の各稜に取り付けた調光可能 な $40 \mathrm{~W}$ 白色けい光ランプ（各稜に 1 本）によって，指 向性の光は, 視対象を含む鉛直面内で対象物を中心とす る半径 $117 \mathrm{~cm}$ の円周上に, $15^{\circ}$ 間隔で設置した $150 \mathrm{~W}$ 反対形白熱電球によって得た. 電球を固定したアームは 


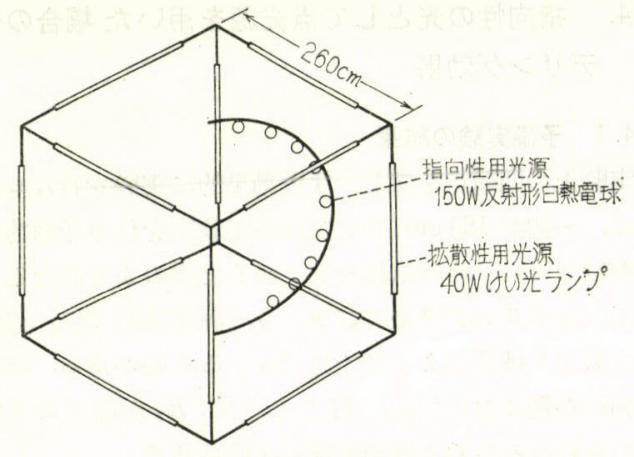

図 5 実験装置 (実験 $1 \sim 4$ )

任意の方位角に設定可能である.実験室は不規則な反射 光を防ぐために全体を暗幕で辂おい, 観測用の空を作っ た. 視対象物を置く中心での拡散性の光による照度のば らつきは $3 \%$ 以内に拈さえることができた. 視対象物と しては, 人の顔を想定してマネキン人形頭部（女性, 図 6)・を採用した。

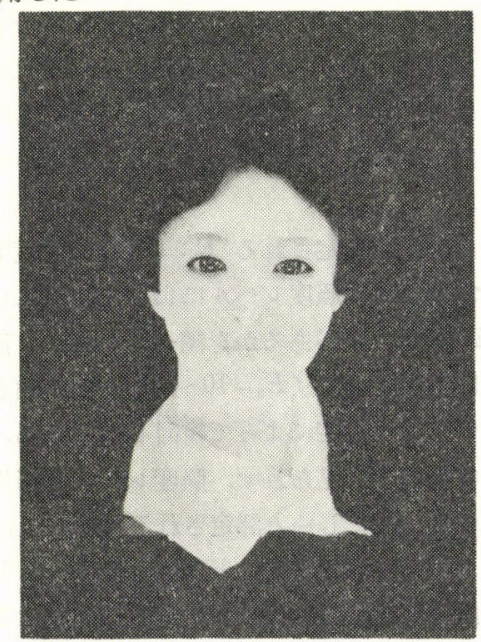

図 6 視 対 象 物

\section{3 実験の方法}

実験は拡散性の光の照度を一定に保ち, 指向性の光の 強さを種々に変化させて, 視対象の好ましいモデリング 効果を観測者に評定させることによって行ない，具体的 には次の二つの測定を実施した.

実験 1 種々の $\alpha, \varphi$ の条件のもとに, 視対象のモ デリング効果がもっとも好ましいと思われる $E: E_{s}$ を 評定させる。

拡散性の光を $2001 \mathrm{x}$ 亿保ち, 指向性の光を調光器によ って変化させて好ましい $\boldsymbol{E}: E_{s}$ を評定させた．ところ でモデリング効果の好ましさと $\boldsymbol{E}: E_{8}$ の関係には, 図 7 亿示すように典型的な二つのタイプがある. 前者の山 型の特性の場合には，好ましい $\boldsymbol{E}: E_{s}$ を評定すること は容易であるが, 後者の台形型の特性の場合には好まし い $\boldsymbol{E}: E_{s}$ を一点に定めることは困難である.そこで本
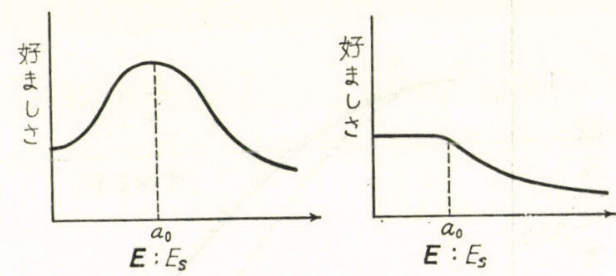

図 7 好ましさと $\boldsymbol{E}: E_{8}$ の関保

実験は $a_{0}$ を評定させるようにした、実験は十分の 訓練 の後, 同じものを 2 度行ない, 2 回の再現性で結果の信 頼性をチェックした.

実験 2 種々の $\varphi, \alpha, \boldsymbol{E}: E_{s}$ の条件下に扔かれた 視対象物を図 8 に示す「平板な感じ一明暗の差が強い」 の 7 段階の尺度上で絶対評定を行なわせる. $\boldsymbol{E}: E_{s}$ の 変化の方法は, 0 から 2.5 まで 0.25 間隔で連続的に上昇 させて提示するものと, ランダムに提示するものの二と 扣りである. 測定結果の信頼性は連続上昇提示とランダ ム提示の結果の再現性でチェックした.な㧍, 連続して 多数の測定を行な党ば, 疲労のための感覚反応が鈍くな つたり, あるいはまた心的飽和のため判断が簡略化され たりして, 誤差を生じることがあるので, 実験に際して は適当に休息をとるよう配慮した。

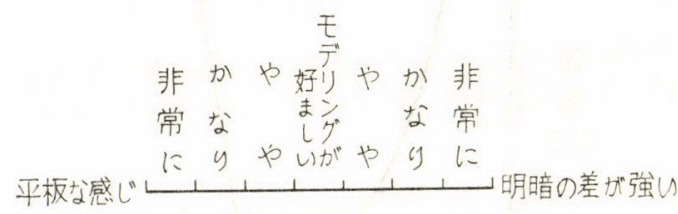

図 8 測定尺度

変化させた照度ベクトルの方向は, 実験 1,2 と次 のと抢りである.

$$
\varphi=10 \sim 120^{\circ}, 10^{\circ} \text { 間隔, } \alpha=-45 \sim 90^{\circ}, 15^{\circ} \text { 間隔 }
$$

被験者は実験 1 が 27 名（20 35 歳, 男 22 名, 女 5 名), 実験 2 が 15 名 (20 35 歳, 男 11 名, 女 4 名) で 西る. 被験者の選択に際して特別の条件は考慮しなかっ たが，矯正視力が正常（1.0 以上）であるかをチェック した、また実験に参加した被験者は感覚的に特異な点は 見い出されず，一般の人々の代表と考劣てさしつかえな いと推定される人間であった。

\section{4 結果と考察}

結果の信頼性を再現性でチェックしたところ，いずれ も 3 名の被験者のデータが悪かったので，これを除外し て整理した.

\section{4.1 好ましい光の方向}

実験 2 亿掓ける絶対評定の結果, 観測者が測定尺度上 で，モデリング効果が好ましいと評定した個数を照度べ クトルの方向に対して調べると図 9 のよらになる.図 に沶いて，縦軸は観測者が好ましいと評定した個数の総 

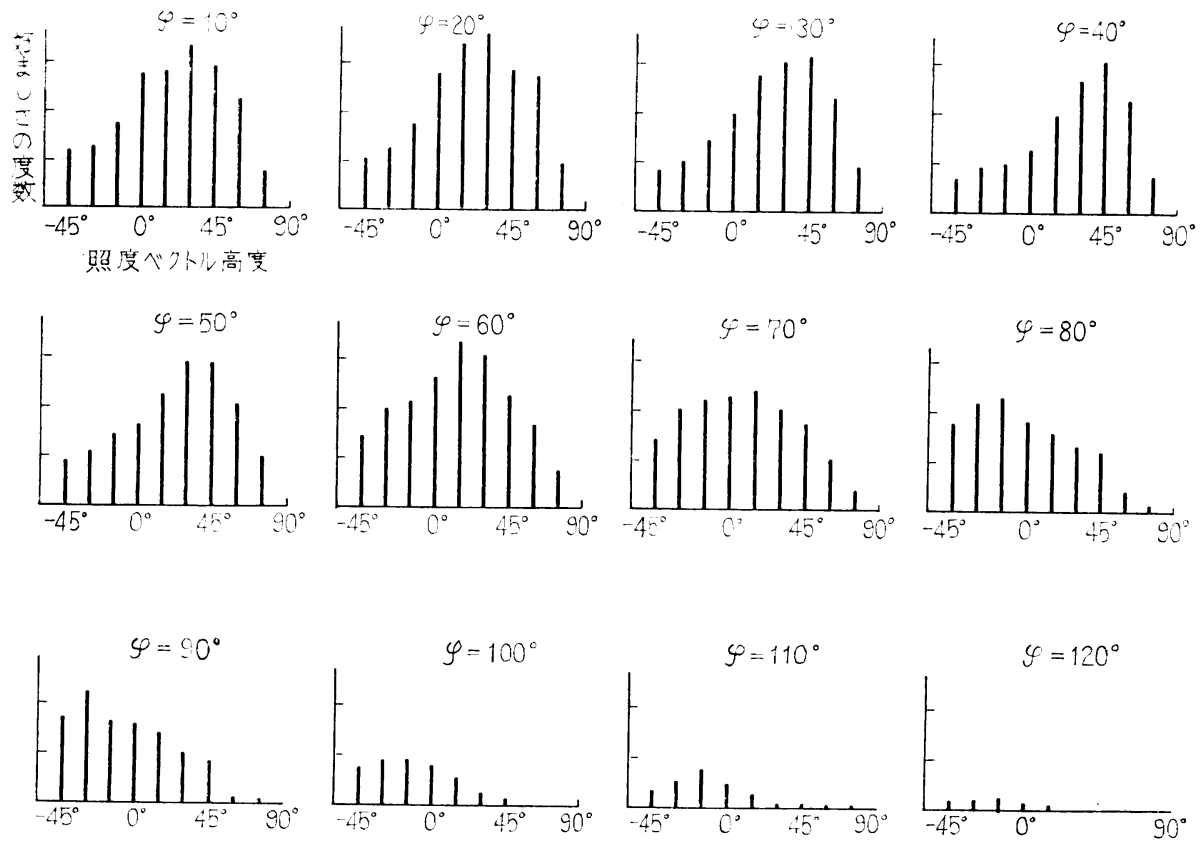

図9好ましさの度数分布

横軸：照度べクトルの高度乘軸：好ましさの度数

和を, 横軸は照度ベクトルの高度を示している. 分布の 傾向から次のことが明らかとなる.

(1) $\varphi$ が比較的小さいとき $\left(10 〜 50^{\circ}\right)$ は，下方また は上方からの光より, 斜め上方からの光のほうが好まし い.

(2) $\varphi \geq 30^{\circ}$ になると， $\varphi$ の大きさとともに好ましい $\alpha$ の範囲はしだいに下方汇移ってくる. 好ましさの度数 が最大を示すのは $\varphi=30 \sim 40^{\circ}$ のとき $\alpha=45^{\circ}, \varphi=50^{\circ}$ のとき $\alpha=30^{\circ}, \varphi=60 \sim 70^{\circ}$ のとき $\alpha=15^{\circ}, \varphi=80^{\circ}$ の とき $\alpha=-15^{\circ}, \varphi=90^{\circ}$ のとき $\alpha=-30^{\circ}$ となる.

(3) $\varphi=30^{\circ}, 50^{\circ}$ の度数分布に比へ $\varphi=40^{\circ}$ の度数分 布は総体に低くなる.これは $\varphi=40^{\circ}$ のとき鼻の影が好 ましくないところにできるためと考觉られる.

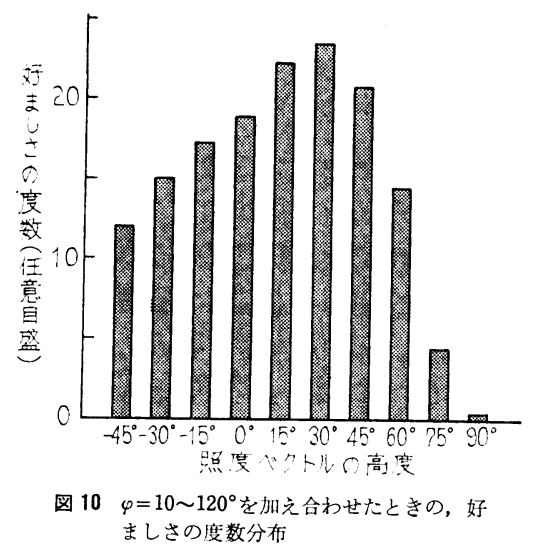

Vol. 59 No. 1
(4) $\varphi \geq 80^{\circ}$ になると上方からの光より，下方からの 光のほうがむしろ好ましくなる。

(5) $\varphi \geq 100^{\circ}$ になると, 好ましさの度数は急激汇減少 する.

$\varphi$ を $10^{\circ}$ から $120^{\circ}$ まで変化させたときの好ましさの 度数を，すべて加え合わせると図 10 を得ることができ る. 図から次のことが明らかとなる.

（1）総体として好ましい照度べクトルの高度は, 斜め 上方にある。

（2）極端に上方の光 $\left(\alpha=75^{\circ}, 90^{\circ}\right)$ は，好ましいモ デリング効果を与えない。

次に照度とベクトルの高度を綎軸, 方位を横軸として 好ましいと評定された度数の相対的に多いところ゙を領域

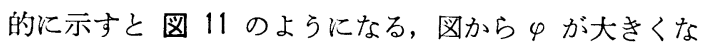
るにしたがい，好をしい $\alpha$ の範囲が下方に移動していく ことを直視的に知ることができる．好ましいとした個数 の総数が 43 以上になるところを，好ましい光の方向と 仮定すると，好ましいモデリング効果を与える光の方向 は，表 1 のようにまとめることができる.

表 1 好玉しい照度ベクトルの方向

\begin{tabular}{c|c||c|c}
\hline$\varphi$ & $\alpha$ & $\varphi$ & $\alpha$ \\
\hline $10^{\circ}$ & $0 \sim 60^{\circ}$ & $60^{\circ}$ & $0 \sim 30^{\circ}$ \\
$20^{\circ}$ & $0 \sim 60^{\circ}$ & $70^{\circ}$ & $-15 \sim 15^{\circ}$ \\
$30^{\circ}$ & $15 \sim 60^{\circ}$ & $80^{\circ}$ & $-30 \sim 0_{\circ}$ \\
$40^{\circ}$ & $30 \sim 60^{\circ}$ & $90^{\circ}$ & $-30^{\circ}$ \\
$50^{\circ}$ & $15 \sim 45^{\circ}$ & & \\
\hline
\end{tabular}




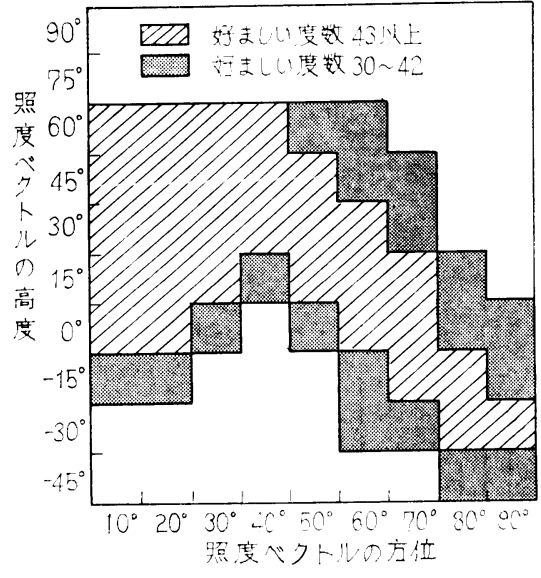

图 11 好ましい照度べクトルの領域

\subsection{2 好ましい照度ベクトル：スカラ照度}

\section{4.2.1 最適值評定における好ましい $\boldsymbol{E}: E_{s}$}

実験 1 に拈ける 2 回の測定結果を平均し, さらに観測 者 24 人の平均を求めると図 12 のようになる. 図は横 軸を照度べクトルの高度とし, 絽軸をもっとも好ましい とされた $\boldsymbol{E}: E_{s}$ として方位ごとに示したものである.

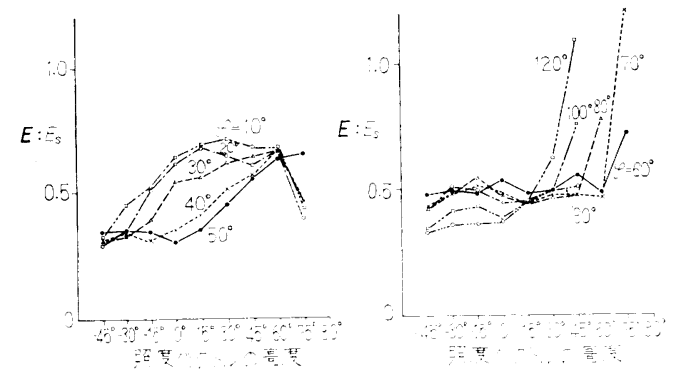

因 12 最高値評定にお㚈る好ましい $E: E_{s}$

四から次のことが明らかとなる。

(1) $\varphi=10 \sim 50^{\circ}$ のとき

(a) $\alpha$ が大きくなるにしたがって，好むしい $\boldsymbol{E}: E_{s}$ はしだいに大きくなり, 最大を示して再び減少する $(\varphi=$ $50^{\circ}$ を除く).

これは下方からの光，または極端に上方からの光に対 しては好ましくない影ができ，これが好ましい $\boldsymbol{E}: E_{s}$ を低下させたためと考えられる。

(b) $\varphi$ が大きくなるにしたがって，好ましい $\boldsymbol{E}: E_{s}$ は総体に小さくなる．これは光が側方にいくにしたがっ て明暗の差が大きくなってくるためと考えられる.

(2) $\varphi=60 \sim 120^{\circ}$ のとき

(a) $\alpha$ がある值以上になると，好ましい $\boldsymbol{E}: E_{s}$ は急 に大きくなる，そしてこの立ち上がり点は $\varphi$ の增加とと もに $\alpha$ の小さい注らに移動してくる. 立ち上がり点は $\varphi$ $=60 \sim 70^{\circ}$ のとき $\alpha=60^{\circ}, \varphi=80^{\circ}$ のとき $\alpha=45^{\circ}, \varphi=$ $100 \sim 120^{\circ}$ のとき $\alpha=30^{\circ}$ である.
急激な立ち上がりが見られるのは，指向性の光が頭髮 の陰になって効果が著しく弱くなるためと考兄られる.

(b) 立ち上がり点より小さい $\alpha$ の領域では，好ましい $\boldsymbol{E}: E_{s}$ は注涪平担な特性を示し， $\varphi$ の違いによって大き

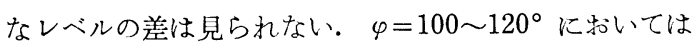
多少レベルが下っているが，これは好ましくない影の影 響によるものと考学られる. 平担な特性を示すのは $\varphi \geq$ $60^{\circ}$ になると，指向性の光が鼻のかげになって片面には あたらなくなって明暗の美が弱くなり， $\alpha$ による差異が 小さくなるためと考えられる.

\section{4.2.2 絶対評定における好ましい $E: E_{s}$}

実験 2 に打いて, 観察者が測定尺度上でモデリング効 果が好ましいと評定したときの $\boldsymbol{E}: E_{s}$ の平均值を照度 ベクトルの力向ごとに求めてみる.

平均值の求め方は, 単純に全観測者の平均を求める方 法と, 観測者ごとに平均を求めて, これの全観測者の平 均を求める方法が考兄られる. 評定基準の観測者による 個人差が小さいときは，両方法による結果の差異は活と んど見られないが，個人差が大きいときはその差異も大 きくなる. 個人差が大きいときは前者の方法では, 評定 基準の甘い観測者（すなわち，モデリング効果が好まし いと評定する度数の多い観測者）にウェイトがかかり, 平均值としての意味がいくぶんそこなわれる，そこでこ こでは後者の方法によって平均值を求める. 平均值を求 ぬ， $\boldsymbol{E}: E_{s}$ を連続的に上昇させて提示した場合と， ラ ンダムに提示した場合の結果を比較したら, 両者の差異 は活とんどなかったのでここでは両方の平均值を示す ことにする.

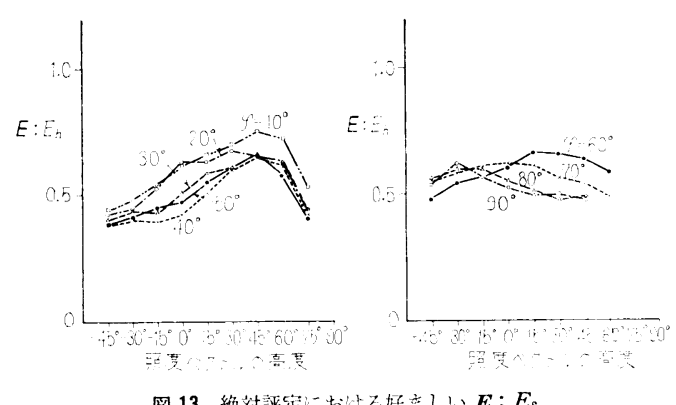

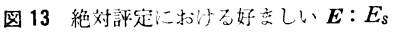

モデリング効果が好ましいと評定したときの $\boldsymbol{E}: E_{s}$ の平均值を, 照度べクトルの力向ごと注求めると図 13 のようになる. 図には $\varphi \geq 100^{\circ}$ の場合の結果は示してい ないが，これは好ましいと評定する観測者の数が少なか ったために省略したものである. 四からべクトルの方向 によって好ましい $\boldsymbol{E}: E_{s}$ が，どのように変わるかを知 ることができる，具体的には次のことが明らかとなる.

(1) 好ましいと評定された $\boldsymbol{E}: E_{s}$ の $\alpha$ による変化の 傾向は, 最適值評定に拈ける好をしい $\boldsymbol{E}: E_{s}$ の傾向と 
注ぼ同じである。

(2) しかし，好ましいと評定された $\boldsymbol{E}: E_{s}$ のレベル は最適値評定の結果より高い.

この理由は次のように考えることができる.

好ましさと $\boldsymbol{E}: E_{s}$ の関係は，好ましいと評定された 度数分布（図 14 に $\varphi=40^{\circ}, \alpha=30^{\circ}$ のときの度数分布 を示しているが，その他の $\varphi, \alpha$ でも同じような分布特 性を持っている）から，図 14 のような特性曲線（小さ い領域で急峻な，大きい領域でなだらかな）を持つこと が予想される。

このため，好ましさがある基準值 $B_{0}$ 以上になる場合 (このとき観测者は, 测定尺度上でモデリング効果が好 ましいと評定する) の $\boldsymbol{E}: E_{s}$ の平均値 $a_{1}$ は, 好ましさ の最大を示すときの $a_{0}$ （最適値評定においては，この点 でもっとも好ましいと評定する）より大きくなる。

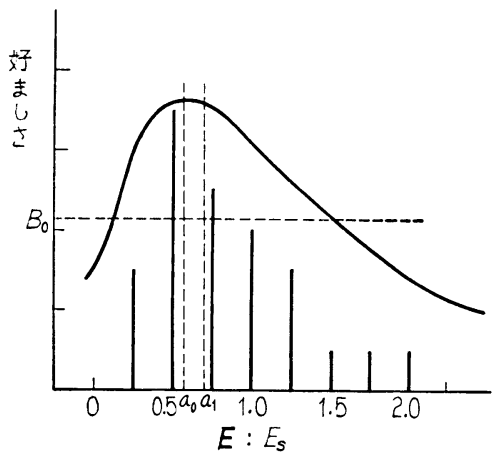

図 14 好むしさと $E: E_{s}$ の関係

(3) $\varphi \geq 60^{\circ}$ でも山型の特性を示す.

最適值評定においては， $\varphi \geq 60^{\circ}$ ではほぼ平担な特性 を示したが，絶対評定においてはなだらかな山型の特性 を示す.この違いは好ましさのとらえ方の違いによるも のと考えられる.

(4) $\varphi \geq 60^{\circ}$ において，好ましい $\boldsymbol{E}: E_{s}$ の最大值を与 える $\alpha$ の值は, $\varphi$ が大きくなるにしたがって小さくな る.これは $\varphi$ が大きくなるにしたがって， $\alpha$ の小さい領 域の好ましい $\boldsymbol{E}: E_{s}$ が，大きい流うへひろがってくる ためと考えられる.

\subsubsection{3 モデリング効果の好ましい $\boldsymbol{E}: E_{8}$ の領域と 好ましくない $\boldsymbol{E}: E_{s}$ の領域}

好ましい $\boldsymbol{E}: E_{s}$ の值が，どれくらいのレベルである かは図 12, 図 13 によって知ることができる.

次に好ましい $\boldsymbol{E}: E_{s}$ の幅はどの程度であるか, 平板 な領域, どぎつい領域はどうなるかを調べてみる。

観测者が， 7 段階の测定尺度上でモデリング効果が好 ましいとしたときの $\boldsymbol{E}: E_{s}$ の上限と下限 $\left(\boldsymbol{E}: E_{s}\right.$ の 0 〜 25 の変化に対して, 好ましいと評定される $E: E_{s}$ は複 数個得られる. このとき最大の $\boldsymbol{E}: E_{s}$ を上限, 最小の
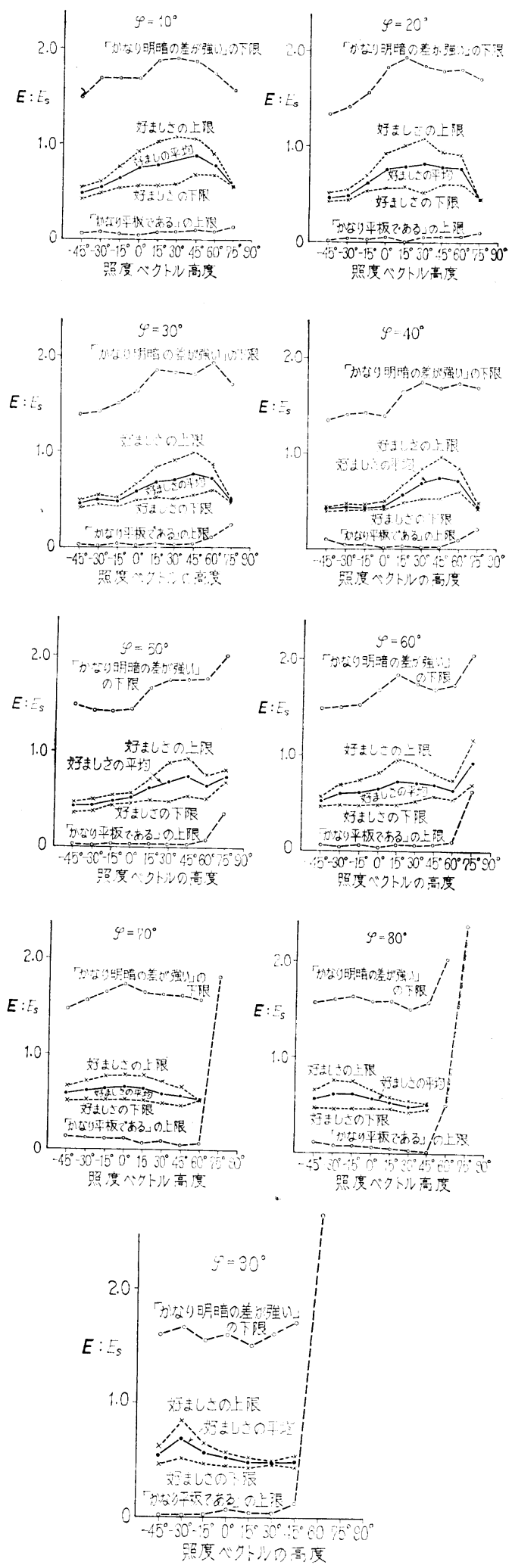

図 15 好ましい $E: E_{8}$ の範围

Vol. 59 No. 1 
$\boldsymbol{E}: E_{s}$ を下限と考える)，かなり平板であると評定した ときの $\boldsymbol{E}: E_{s}$ の上限，かなり明暗の差が強いと評定し たときの $\boldsymbol{E}: E_{s}$ の下限をとり，全観測者のそれぞれの 平均を求めると図 15 を得ることができる．図からモデ リング効果の好ましい領域, 好ましくない領域がベルト ルの方向によって，ぞのように変様するかを知ることが できる. 感覚的，主観的評定であるため緟密な意味での 境界線を引くことはできないが，一応の目やすとして，

(1) かなり平板であると評定された $\boldsymbol{E}: E_{s}$ の上限の 值は，視対象を好ましくみせるのにぎりぎりのソフトな モデリングを与える $\boldsymbol{E}: E_{s}$.

（2）好ましいと評定された $\boldsymbol{E}: E_{s}$ の上限と下限では さまれた領域は，好ましいモデリングを与える $E: E_{s}$ の領域.

（3）かなり明暗の差が強いと評定された $\boldsymbol{E}: E_{s}$ の下 限の值は, 許容し得る限界の Harsh*なモデリングを与 える $\boldsymbol{E}: E_{s}$.

と考えてよいであろう。このようにすると図から次のこ とが明らかとなる。

(1) 好ましいモデリングを与える $\boldsymbol{E}: E_{s}$ の領域は, ほぼ 0.5〜1.0 の籁囲にある.

(2) ソフトなモデリングを与える $\boldsymbol{E}: E_{s}$ の領域は, 0.1 以下である.

(3) どぎついモデリングを与える $\boldsymbol{E}: E_{8}$ の領域は, 1.5 以上である.

(4) 好ましいモデリングを与える $\boldsymbol{E}: E_{s}$ の幅は, 極 端に上方からの光, および極端に下方からの光に対して 狭くなる. 好ましい $\boldsymbol{E}: E_{s}$ の幅がもっとも広がるのは, $\varphi=10 \sim 50^{\circ}$ の場合 $\alpha=45 \sim 60^{\circ}$ のとき, $\varphi$ が $60^{\circ}$ 以上に なると $\alpha$ の小さいほらにだんだん移動し， $\varphi=80 \sim 90^{\circ}$ の場合は $\alpha=15 \sim 30^{\circ}$ のとき最大となる.

(5) $\varphi ， \alpha$ の大きい領域では, ソフトなモデリングを 与兄る $\boldsymbol{E}: E_{s}$ が急激に大きくなる.これは指向性の光 が頭髨の陰になって，モデリング効果が弱くなるためと 考えられる.

\section{5. 光源の色温度の影響}

実験 1 , 実験 2 亿おいては, 日常の照明として広く利 用されているといら理由から，拡散性の光として白色け い光ランプを使用した. このため色温度の異なる光源の 使用（昖散性の光として白色けい光ランプを，指向性の 光として反射形白熱電球を使用）が，モデリング効果の 評価に影響を与えるかもしれないという問題を生じた （補足的に行なった視対象をりんご，パイナップル， ハ ナナ，みかんの静物とした実験結果によると，色の好ま しさの評価が，モデリング効果の評価に混入することが
明らかになった)。

そこでこの色温度の影響を検討するために，拡散性の 光として白色けい光ランプを使用した場合と，白熱電球 とほぼ同じ分光エネルギー分布を持つ温白色けい光ラン プを使用した場合との比較的実験（実験 3 ）を行なっ た. 測定は実験 1 と同じ要領で行ない,もっとも好まし いモデリン効果を与える $\boldsymbol{E}: E_{s}$ を評定させた．被験者 は 5 人で, 変化した照度ベクトルの方は次のと拈りで ある.

$$
\left\{\begin{array}{l}
\varphi=10^{\circ}, 30^{\circ}, 50^{\circ}, 70^{\circ} \\
\alpha=-30^{\circ}, 0^{\circ}, 30^{\circ}, 60^{\circ}
\end{array}\right.
$$

表 2 払散性の光として白色けい光ランプを用いたときと, 温白 色けい光ランプを用いたときの好ましい $\boldsymbol{E}: E_{8}$ の相違

\begin{tabular}{r|r|r|r|r|r|r|r|r|r}
\hline$\varphi$ & \multicolumn{1}{c|}{$\alpha$} & \multicolumn{1}{|c|}{$F_{0}$} & $F(0.05)$ & 有意の差 & $\varphi$ & $\alpha$ & \multicolumn{1}{c|}{$F_{0}$} & $F(0.05)$ & 有意の差 \\
\hline $10^{\circ}$ & $60^{\circ}$ & 5.20 & 4.22 & あり & $50^{\circ}$ & $60^{\circ}$ & 1.41 & 4.22 & なし \\
$10^{\circ}$ & $30^{\circ}$ & 0.08 & 4.18 & なし & $50^{\circ}$ & $30^{\circ}$ & 0.81 & 4.22 & なし \\
$10^{\circ}$ & $0^{\circ}$ & 0.04 & 4.21 & なし & $50^{\circ}$ & $0^{\circ}$ & 0.86 & 4.21 & なし \\
$10^{\circ}$ & $-30^{\circ}$ & 0.86 & 4.21 & なし & $50^{\circ}$ & $-30^{\circ}$ & 0.01 & 4.26 & なし \\
$30^{\circ}$ & $60^{\circ}$ & 0.24 & 4.21 & なし & $70^{\circ}$ & $60^{\circ}$ & 2.02 & 4.17 & なし \\
$30^{\circ}$ & $30^{\circ}$ & 0.94 & 4.20 & なし & $70^{\circ}$ & $30^{\circ}$ & 0.24 & 4.21 & なし \\
$30^{\circ}$ & $0^{\circ}$ & 0.04 & 4.20 & なし & $70^{\circ}$ & $0^{\circ}$ & 1.22 & 4.17 & なし \\
$30^{\circ}$ & $-30^{\circ}$ & 0.77 & 4.24 & なし & $70^{\circ}$ & $-30^{\circ}$ & 0.22 & 4.26 & なし \\
\hline
\end{tabular}

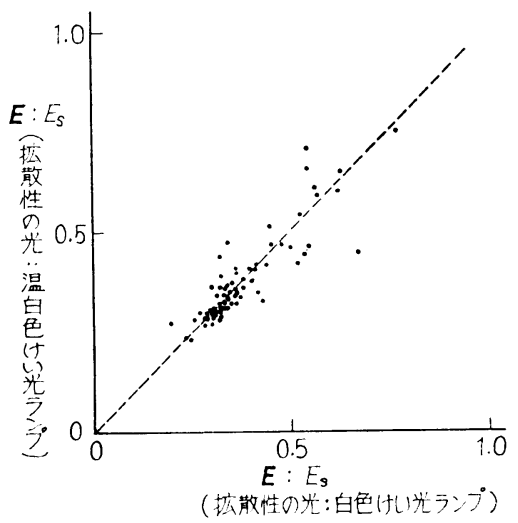

図16昖散性の光として白色けい光ランプを用い温白色けい 光ランブを用いたときの，好ましい $\boldsymbol{E}: E_{s}$ の相違

好ましいモデリング効果を与える $\boldsymbol{E}: E_{s}$ について， 両実験結果の評定值に，有意の差があるか否かを $\mathrm{F}$ 検定 によって調べた. 表 2 はとの結果である. 表から $\varphi=$ $10^{\circ}, \alpha=60^{\circ}$ の場合を除けば, 評定值の母平均に有意の 差（5\%有意水準）がないことが判明する. 両実験結果 を直交座標軸に示すと図 16 のよらになる。，三の 例外を除けばほぼ $45^{\circ}$ 線上に分布している，視対象を事 験 2 で使用したマネキン人形に限定するとき，払散性の 光として白色けい光ランプを用いた場合と，温白色けい 光ランプを用いた場合とでは，好ましい $\boldsymbol{E}: E_{s}$ に有意 の差はないといってもよいであろう.

(つづく)

\footnotetext{
* Cuttle 汢明暗の差が強すぎるのを Harsh と呼んでる.
} 